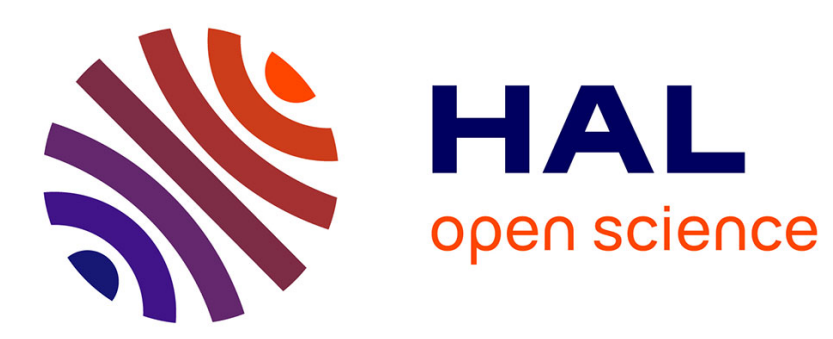

\title{
Celebrate Chemistry. Recent Results of Molecular Gastronomy
}

Herve This

\section{To cite this version:}

Herve This. Celebrate Chemistry. Recent Results of Molecular Gastronomy. European Review, 2013, 21 (2), pp.158-174. 10.1017/S1062798712000336 . hal-01627232

\section{HAL Id: hal-01627232 \\ https://hal.science/hal-01627232}

Submitted on 3 Jun 2021

HAL is a multi-disciplinary open access archive for the deposit and dissemination of scientific research documents, whether they are published or not. The documents may come from teaching and research institutions in France or abroad, or from public or private research centers.
L'archive ouverte pluridisciplinaire HAL, est destinée au dépôt et à la diffusion de documents scientifiques de niveau recherche, publiés ou non, émanant des établissements d'enseignement et de recherche français ou étrangers, des laboratoires publics ou privés. 


\title{
Celebrate Chemistry. \\ Recent Results of Molecular Gastronomy
}

\author{
Hervé This \\ UMR 1145 INRA AgrpParisTech UMR 1145, Group of Molecular Gastronomy, 16 rue \\ Claude Bernard, 75005 Paris, France. E-mail: herve.this@agroparistech.fr
}

Much confusion between science and technology (between science and technique the difference seems to be clearer) can be observed in today's public debates about complex issues such as the healthiness of food. Showing clearly the difference is important not only to solve these issues on a sound basis, but also for funding science, for the organization of improved relationships between scientific laboratories and the industry, and also for a better appreciation of the advances of both fields. The difference is particularly important about food, where the situation is paradoxical: in homes, individuals cook almost as they would have done centuries ago, wasting up to $80 \%$ of the consumed energy for processes whose goal was never rationalized (a pan on a gas stove receives four times less energy than the surrounding room). A lot of toxic compounds are consumed daily without reluctance, and even when the public is being told of the risks, no behavioural change is achieved. Simultaneously, consumers fear being poisoned when they eat food from the food industry that includes additives, in spite of decades of scientific studies of the security of such compounds. All this seems to be the result of 'ilchemiteracy', the ignorance of the wonderful world of molecules, compounds, processes. Indeed, much has to be done in order to improve this situation, and even among chemists. One should probably make a distinction between chemistry, as a science, looking for the mechanisms of phenomena (reorganization of atoms), and technology, i.e. improving technique using the results of science (but not only that). It should be explained that there will never be any 'chemistry' in the kitchen, or in the plate, but only atomic assemblies that are sometimes reshuffled by cooks as chemistry, producing knowledge, does not produce food! In this regard, the scientific discipline called 'Molecular Gastronomy', introduced by N. Kurti and H. This, in 1988, should be helpful from many points of view. First, it produces knowledge on culinary transformations. This scientific knowledge can be used by technology, and technique later on, but it can also change the mind of the public. A new appreciation of food can be the result of scientific explorations of cooking. Then, educational programmes based on Molecular Gastronomy can be introduced at any level of education, general or professional, from elementary schools up to universities. This will certainly lead to new practices. Indeed, many new culinary methods and food systems were 
introduced over the past ten years, and students at primary schools running 'Ateliers expérimentaux du goût' learn how to make chocolate mousse without eggs, or how to make one cubic metre of whipped egg white from one egg white. In the field of restaurants, the culinary trend called Molecular Cuisine is still developing in the world, but a new way of cooking called 'Note by Note Cuisine' is being introduced: it means cooking with pure compounds, just as acoustic music is using only acoustic waves of definite frequency. The first Note by Note meals were produced during the last 3 years, and one Note by Note dinner was even offered to about 150 guests the day before the Opening Event of the International Year of Chemistry in 2011. New moves are in progress.

Today, as there is much confusion between science and technology up to the point that some even speak of 'technosciences', , it is useful that the public can understand clearly what science is, and how technology is different from it (for technique, the difference seems to be clearer, except when people use the word 'science' for 'knowledge', such as in 'science of cooking'). This difference is important both for the right funding of science (which amount is really given - by States or by industrial companies - to science, in view of further developments, and which to technology, contributing to technical developments?), but also for the organization of sound relationships between scientific laboratories and the industry, and for a better appreciation of the advances of both fields.

In no field is this difference more important than that of food, where the situation is paradoxical: whereas probes are being sent toward Mars, whereas all fields have been modified by technological advances, whereas we use cars, planes, computers, etc, individuals at home cook almost as they would have done centuries ago, using the same meats, fish, vegetables, fruits, processed in the same kind of vessels (all right, the metals of modern pans do not oxidize but this is a very slight change, compared with the possibilities, including using other tools rather than pans), wasting up to $80 \%$ of the consumed energy (because the real goal of these processes was never rationalized: why is food heated?).

As 2011 was the International Year of Chemistry, it is funny to look at the menu of the dinner that was served in 1911 to Marie Curie upon receiving the Nobel prize: ${ }^{2}$ Consommé Doria, Suprême de turbotin cardinal, Poularde fermière, Chaud-froid de cailles, Salade mâche, Fonds d'artichauts duchesse, Charlotte Rachel, Fruits. This menu, then, included turbot, chicken, quails, salad, artichokes, apples, and so on. Plant and animal tissues: nothing really new since the very beginning of the humankind, even if we have to admit that some new culinary preparations were introduced in the course of history (for example, emulsions such as mayonnaise were unknown in culinary practices before the 17 th century). ${ }^{3}$ Another way to consider the question of the very slow innovation in food and culinary practices is to recognize that such a menu could well be served today! The lesson is: there are very slow and minor changes, as far as food is concerned, probably because humans are primates for which food neophobia is an important reflex (this means that new food cannot be easily consumed, as it could be potentially poisonous). ${ }^{4}$

Let us look at this question differently. The science of chemistry (should we call it differently from the technique of making new compounds? Atomology? Physical chemistry?) grew from techniques called 'chemical arts ${ }^{5}$ (making candles, drugs, metals, paintings, coats, cosmetics, food), and it yielded in return applications in most fields, which as a result underwent tremendous transformations (just remember the history of 
artificial colorants, ${ }^{6}$ but also of drugs). However, in food, almost no change was observed, and today big food companies still make money selling packages containing fish with sauce, pizzas, potato salads, and so on. The amount spent by this food industry is about 150th of that spent by the drug industry. On the whole, human food did not really change.

The worst of this is that traditional culinary processes certainly do not guarantee safety and health, in spite of much advertising and discussions about this question. ${ }^{7}$ More than two millennia ago Hippocrates said 'From your food you will make your medecine, ${ }^{8}$ but in fact before the nutritional sciences started analysing the physiology of food consumption and of the metabolism, the possibilities of action were unclear. In the 15th century, for example, when Bartolomeo de Sacchi ('Platina') discussed the 'food and health' question in his De honesta voluptate et valetudine, ${ }^{9}$ he was only using the four 'humours' theory to guide culinary practices, and it is interesting to observe that when today we eat ham with cantaloupe, we still unconsciously apply such theories. In spite of advances in nutritional science, we still eat very irrationally. For example, meat cooked on barbecues contains up to 2000 times more carcinogenic benzo[ $\alpha$ ]pyrenes than is admitted by law in industrial food products, such as smoked fish, but very few of us would be willing to give up his or her barbecue when the weather is fine. ${ }^{10}$

This observation should lead us to discuss the issue of 'good food'. We have to recognize that food owes its 'goodness' to culture, and education: we recognize as good what we were trained to appreciate when young (and this should certainly be studied very thoroughly). ${ }^{4}$ For example, Munster cheese is considered 'good' by Alsatians, but it is a stinky thing for other groups. Grilled scorpions are considered a delicacy by the Chinese but appear inedible for many individuals from western countries. And we do not even mention frogs and snails, which make for heated debates between France and England, for example.

Whereas toxicology can tell us a lot about toxic compounds in obviously toxic food (epidemiology can demonstrate a higher incidence of digestive tract cancers in the countries of the North of Europe, where smoked products are widely consumed), ${ }^{11}$ some big issues remain. For example, ${ }^{12}$ estragole (methyl chavicol, or 1-methoxy-4-2-propenyl benzene) has been demonstrated to be genotoxic and carcinogenic with no minimal dose (the existence of a threshold cannot be assumed and the European Committee of Experts on Flavouring Substances could not establish a safe exposure limit), but no epidemiologcial study showed that basil (Ocimum basilicum) or tarragon (Artemisia dracunculus L.) consumption is associated with increased mortality (estragole represents up to $65 \%$ of essential oil of tarragon, and 50\% in basil; it is also present in anis seeds, fennel, etc). Indeed, estragole is not toxic by itself, but by its hydroxy derivative, and it could be possible that various P450 cytochromes metabolize the compound differently depending on specific human groups.

For some food, the public does not want to know about the dangers. For example, whereas fatty acids are the topic of many scientific and public discussions, nobody wants to know which ones are present in chocolate, and whereas we want to get slim and avoid sugar, we say that chocolate is good for the health 'because of magnesium', ${ }^{13}$ forgetting (or rather, trying to forget) that chocolate is about $50 \%$ fat (triglycerides, not fatty acids) and $50 \%$ sucrose, with only $0.01 \%$ of magnesium.

More generally, a lot of toxic compounds are consumed without reluctance, and even when the public is being told of the risks, no behavioural change is achieved. At the same 
time, when the food industry is using additives (whose safety has been extensively studied), in quantities much lower than those consumed at home, consumers fear being poisoned. All this is based in part on 'ilchemiteracy', the ignorance of chemistry, of the wonderful world of molecules, compounds, processes, and so on.

\section{Should We Not Consider Chemistry as a Science? Applied Sciences don't Exist Anyway!}

In fact, much should be done to improve this situation, and even among chemists some clarification is probably needed. What is chemistry, for example? I have the feeling that slogans such as 'Chemistry makes its own object', from the French chemist Marcellin Berthelot, ${ }^{14}$ are bad, because formulas such as this prevent us from clearly understanding that chemistry cannot be a science and a technique at the same time. Is it not time to recognize that there is a clear distinction between chemistry, as a science, looking for the mechanisms of phenomena, ${ }^{15}$ and a technique (making 'products'). If science and technique were the same, should not we not use only one term for the two?

Of course, this last argument is not enough, and we should examine the goals and methods of our science from a historical perspective. First, as mentioned above, there were both alchemy and chemical arts. Then, slowly, a scientific discipline was created, applying a 'method' defined by scientists such as Galileo Galilei, Bacon, and others. ${ }^{16}$ It was recognized that science means looking for the mechanisms of phenomena, using experiments and calculations (according to Galileo Galilei, 'the world is written in mathematical language'). The goal of science was much discussed, but Albert Einstein summarized it when he said 'to lift up a corner of the great veil'. ${ }^{17}$ In this regard, technique and technology are very different from science, because technique means producing products (paintings, coats, drugs, or even food) and technology wants to study technique in order to improve it, using (or not) the advances of sciences.

In fact, the methods of science and of technology are also different, and we propose to acknowledge this in order to improve the education of engineers and technologists (who frequently are also scientifically trained these days). For modern technology, using the latest results of science, young professionals should learn to (1) look for the results of science (where to look for them, understanding them, and so on); (2) filter in this huge corpus what could be useful for their particular field of application; (3) make technological transfers, i.e. using the selected results for specific applications. Even before discussing the methods of science, we see how it is different! Moreover, we also see how 'research' is a confusing word, as it applies to so many different things.

Concerning the method(s) of science (not all sciences: only philosophia naturalis is discussed here), much confusion also remains, probably because modern epistemology, proposed by intellectuals considered (by some) as brilliant (for example the Austro-

American philosopher Paul Feierabend), ${ }^{18}$ frequently prevents us from recognizing that in spite of second-order details, the main method applies. Moreover, modern philosophers wanted to combat a description of science where there was no room for human factors, but as the French philosopher Pierre Thuillier (1927-1998) wrote, it is important to know where one goes too far! ${ }^{19}$ Indeed, it is a paradoxical situation that today many 
students studying science cannot say what science is, and what the scientific method consists of. It is probably important to tell them that such a method contains the following steps: (1) deciding to study a particular phenomenon; (2) quantitative characterization; (3) synthesizing data in laws; (4) finding a theory, a model, behind the laws; (5) deriving a prediction for the theory; (6) the experimental testing of this prediction, in view of refuting the theory; and then back to (2), etc.

In fact, this method can be applied to any field, to any phenomenon, and in particular to phenomena occurring during culinary transformations. Why do popovers and soufflés rise? For decades prior to 1980 , it was thought ${ }^{20}$ that soufflés rise because the air bubbles of the whipped egg white used for such food systems expand with heat, but simply applying the ideal gas law one can calculate easily that a $30 \%$ expansion is the maximum that can be obtained, whereas chefs often achieve $200 \%$ ! The theory was wrong, but this is obvious, as any theory is naturally wrong, and we have to refute theories rather than to demonstrate them (except in mathematics, but mathematics is not a science: it is mathematics). Why do soufflés rise, then? It was easy to measure the pressure or the temperature at various points in soufflés, and in the very beginning of the 1980s I showed that soufflés rise because of water evaporation. ${ }^{21}$ Indeed, this new theory was checked during one meeting of the Group of Study of Culinary Precisions, when two soufflés expanded the same with whipped egg whites and with non-whipped egg whites, being heated from the bottom. $^{22}$

That soufflés rise because of water evaporation is a new theory: how is it wrong? Measuring the mass loss (water) during cooking shows that up to $10 \mathrm{~g}$ can be evaporated during the processing of a $100 \mathrm{~g}$ soufflé, which means that we should get 10 litres of soufflé. If such a volume is not obtained, it is because some steam is lost through the upper surface of soufflés. We now have to focus on this loss, and so on.

Before moving to Molecular Gastronomy, let us conclude this epistemological discussion by saying that first we hope that in the future the word 'chemistry' will be applied only to the technique of making new compounds, that we propose to fight expressions such as 'applied sciences' (if they are sciences, they are not applied, and if application is concerned, it is technology, not science), and let us also recognize that there will never be any 'chemistry' in the kitchen, or on the plate, as chefs are not doing chemistry but only producing 'food'.

\section{Molecular Gastronomy}

Recognizing that phenomena occurring during cooking were not studied by science, the scientific discipline called 'molecular gastronomy' was introduced by the late Nicholas Kurti (Budapest, 1908-Oxford, 1998) and myself, in 1988. ${ }^{23}$ Indeed, our initial title was 'molecular and physical gastronomy', because we used the same idea as for molecular biology, on the one hand, and because Kurti wanted to stress that physics was as important as chemistry in this regard, on the other. However, when I proposed a revision of the scientific programme of the discipline around 2000, I dropped the last part of the name because it was, in effect, useless.

Recognizing that culinary activities have three components, i.e. social, art and technique, we had to consider that the scientific programme of the discipline also has three 


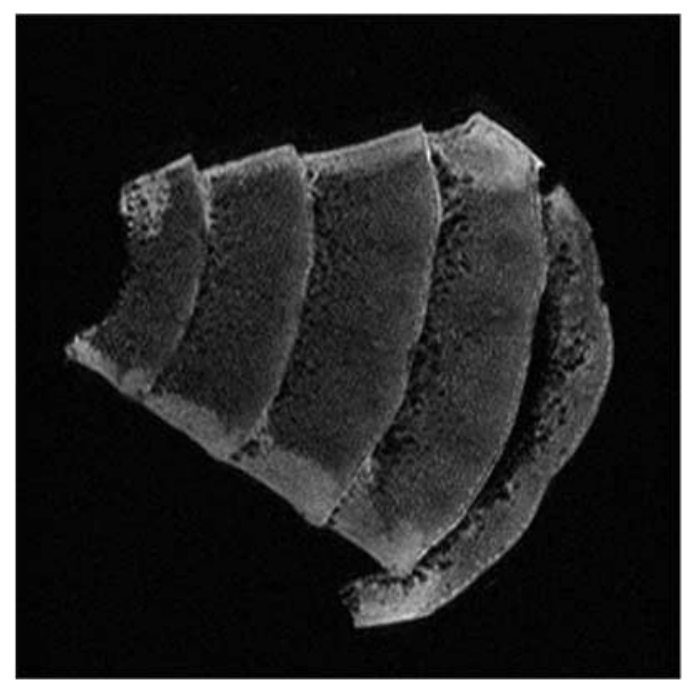

Figure 1. T2 weighted MRI picture of a sample of the bulb of onions Allium cepa L. cut using a culinary knife. The cut parts show a clearer shade, showing the tissues were damaged (to be published).

parts: (1) exploring the technical component of cuisine; (2) exploring (scientifically) the art component of culinary activities; (3) exploring the social component. Concerning technique, a difference was made between 'definitions' of dishes (for example, a 'jam' is obtained by thermally processing fruits with water and sucrose), the 'precisions' (tips, old wives tales, methods, proverbs, etc, such as 'add lemon juice to keep the fruits white', or 'cut the head of roasted suckling pigs as soon as roasting is performed, in order to keep the skin crisp'), and a 'third part' (including cultural discussion, and information of various non-technical kinds). ${ }^{24}$

In the 1980s, the introduction of molecular gastronomy was much needed because science was only considering the chemical composition of food ingredients, or industrial processes. There were almost no studies about the daily meals that people produce in their kitchens. For example, textbooks such as the classic Food Chemistry ${ }^{25}$ contained almost nothing on culinary transformation: even in the 1999 edition of the book, less than $0.5 \%$ of the chapter on meat was describing 'culinary phenomena' (meat shrinkage during heating because of collagen denaturation); most of the chapter described either meat composition and structure, or industrial products (sausages, meat extracts, and so on). And whereas wine is frequently used by cooks in order to add flavour to dishes, particularly sauces ( $48 \%$ of French classical sauces include wine ${ }^{26}$ ), the thermal processing of wine is not considered!

Indeed, even if rationalization of culinary techniques was needed, Kurti and I did not want to make technology. Instead we wanted to make science, because we knew that a lot of phenomena occur during culinary processes. ${ }^{27}$ Wasn't this a chance to discover new mechanisms? New phenomena? Of course, the studies that we were proposing were chemistry and physics, sometimes biology, and of course, in spite of being of a scientific 


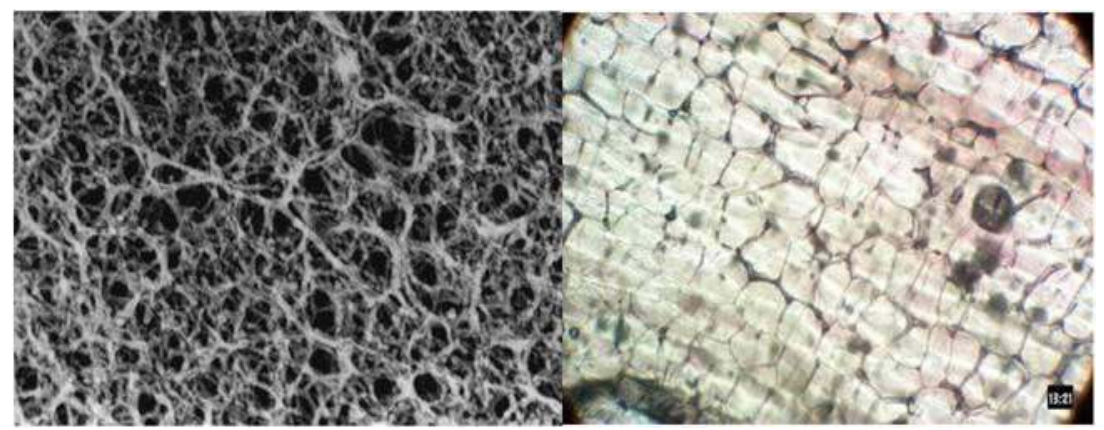

Figure 2. (Colour online) Left, a connected gel (gelatine) and, right, a non-connected gel (Allium cepa tissue) observed using, respectively, electron microscopy and optical microscopy.

nature, there were possibilities for application. Indeed, the discussion of the nature of food can explain those possibilities.

By definition, food is what we eat, and this is why it should be rightly recognized that plants in the fields are not food. Most food is the result of some transformation, even when there is no thermal processing ('cooking'). For example, when onion samples are studied using magnetic resonance imaging, it can be observed that the edges appear brighter than the centre of the samples (Figure 1), which means that the tissues were compressed by the cutting tool (moreover, this compression is proportional to the 'width' of the blade - results to be published). This means that enzymatic reactions are activated (polyphenoloxidases), which goes along with the disappearance of some amino acids, and the formation of compounds having a strong colour and possible flavour. ${ }^{28}$

Let us observe that a lot of confusion remains today about molecular gastronomy, too often confused with 'molecular cuisine', a culinary trend that Kurti and I also promoted. It is also highly surprising that some scientific associations even gave honorary degrees to cooks, as in fact there is nothing in common between cooks and scientists, and no cook, even when applauded by the press, is doing scientific research. ${ }^{29}$

Let us close this section by observing also that expressions such as 'culinary science' are wrong, as is 'the science of good food', sometimes even used in some academic circles: ${ }^{30}$ in the first case, there is a mistake because cooking is no science; in the second case, 'good' is a personal appreciation, which owes nothing to science, but only to history, culture, education, etc.

\section{Complex Disperse Systems}

Considering that most foods are gels (according to the International Union of Pure and Applied Chemistry, gels are colloidal systems with water trapped into a solid network ${ }^{31}$ ), we can now establish that one very important issue of molecular gastronomy is the following. Foods are systems with bioactivity, which means that they contain compounds interacting with sensory receptors, and culinary processes change the release of bioactive compounds, so that one goal is to find out the relationship between processes and 
modifications of bioactivity. One should note that this question is the same for food (the receptors are those of vision, odour, taste, trigeminal, consistency, temperature, satiety) or for drugs (receptors in tissues), for cosmetics and for products of other chemical arts.

This is why for all chemical arts, but also for the scientific study of colloidal systems, we need to be able to establish the relationship between the release of compounds by physical systems and the structure of such systems, of colloidal nature. Earlier it was said that most foods are gels, and it is true that plant tissues, animal tissues, but also jellies, and many other foods are gels, but of different natures. In the case of plant or animal tissues, gels are not connected, which means that compounds cannot easily be exchanged from cell to cell, contrary to coagulated egg white or gelatine gels, or jams, where the diffusion of compounds can easily occur inside the continuous water phase (Figure 2).

In order to be able to recognize the difference between such different systems, but also in order to study the scientific questions of molecular gastronomy in a rational way (from the most 'simple' to the most 'complex'), a 'formalism for the description of complex disperse systems' (DSF: disperse systems formalism) was proposed in 2002. ${ }^{32}$ This formalism recognizes that systems are built from 'parts' of various 'colloidal nature'. When the parts are described by their physical dimension ( 0 for 'dots', i.e. objects having all their dimensions smaller by one order of magnitude or more than a reference dimension; 1 for 'lines', or objects having two dimensions smaller than the reference dimension; 2 for sheets, 3 for volumes) and when the colloidal systems are described considering the nature of phases involved (solid, liquid (water or oil), gas), operators can be applied: + for a mixture, $\times$ for intermixing of two continuous phases, $\sigma$ for superposition, (a) for inclusion, / for random dispersion. ${ }^{33}$ Using such formalism, any food studied up to now could be described using a unique formula, and, better, various categories of gels could be distinguished, i.e. attributed a particular formula. For example, the formula of muscular tissues of animals is $\mathrm{D}_{1}(\mathrm{~W}) / \mathrm{D}_{3}(\mathrm{~S})$, the formula of the parenchyma of plant tissue is $\mathrm{D}_{0}(\mathrm{~W}) /$ $\mathrm{D}_{3}(\mathrm{~S})$, the formula of gelatine gels is $\mathrm{D}_{3}(\mathrm{~W}) \times \mathrm{D}_{3}(\mathrm{~S})$. And it is very easy to describe any material system at a particular scale.

Of course, such formalism can be much improved quantitatively when needed, and material systems can be described at any scale, using a 'reference size', i.e. an interval of sizes where features are considered.

However, as this is explained in detail elsewhere, ${ }^{34}$ let us not continue in this direction, and instead let us say that the AgroParisTech/INRA Group of molecular gastronomy is interested in the question of finding first a formal relationship between the formula $F$ a of system, and the release of specific bioactive compounds, which means studying so-called 'matrix effects', plus finding a relationship between culinary processes (chemical and physical modifications) and the difference of bioactivity, as described by such links. Indeed, ranking the various possible studies according to a 'complexity' degree of processes, one can hope to study faster such questions, because it is likely that elementary studies can be used to study more complex systems. For example, the study of the release of systems having the formula $\left(\mathrm{D}_{0}(\mathrm{O})+\mathrm{D}_{0}(\mathrm{~S})\right) / \mathrm{D}_{3}(\mathrm{~W})$ can probably be made easier by first studying systems having the formulas $\mathrm{D}_{0}(\mathrm{O}) / \mathrm{D}_{3}(\mathrm{~W})$ and $\mathrm{D}_{0}(\mathrm{~S}) / \mathrm{D}_{3}(\mathrm{~W})$ interactions due to the dispersion of both $\mathrm{O}$ and $\mathrm{S}$ can then be investigated. 
Plant tissues being very widely distributed and consumed, exchanges between such tissues and their environment are much studied in our Group. ${ }^{35-38}$ As bioactivity and matrix effects are a focus of our studies, we frequently use quantitative NMR spectroscopy in order to follow changes. We learned to recognize various compounds (saccharides, amino acids, organic acids, etc ) in aqueous solutions in which plant tissues were soaked, in order to get a quantitative determination of the release of such compounds ('markers'), and to see the contribution of the various physiological parts of tissues (parenchyma cells, xylem and phloem), looking for the laws of the release of compounds as a function of time.

Previously, our studies needed much time and effort to get the data, but we recently proposed a new method called 'in situ quantitative NMR', ${ }^{39}$ where we study directly non-modified stripes of plant tissues, along with a capillary tube containing deuterated water (for locking) and one external chemical shift reference. In this way we now get in about 10 minutes the same information which we needed about five days to obtain before (because of sample preparation included extracting, lyophylisation, dissolution in a solvent, second lyophilisation, and so on). The new method has many advantages, such as consuming no organic solvent, needing no preparation of samples, etc, and giving improved results compared with first extraction of compounds and then analysis. For example, we showed that this method can reveal the presence of more glucose in samples of carrot (Daucus carota L.) root than we could determine using NMR spectroscopy of solutions being prepared after extraction according to the most recent method. ${ }^{40}$

Many questions remain in spite of extensive studies of the soaking of plant tissues in aqueous solutions, such as whether the modifications of compounds inside plant tissues during thermal processing are the same as in solutions, outside plant tissues. In addition, we are now working on improving a model of compound transfer from the various parts of plant tissues toward the environment. ${ }^{41}$

\section{Science has many Applications, and Technology is One}

It was shown above why it would be probably better to keep the word 'chemistry' for the implementation of method for making new compounds, and why there are no applied sciences, but this does not mean, of course, that the science has no applications. On the contrary. First, it can produce knowledge on culinary transformations. This scientific knowledge can be used by technology, and technique, later on.

Indeed, at the beginning of the 1980 s we proposed a new way of cooking, which we later called 'molecular cuisine', with the following definition: cooking using new tools, ingredients and methods. Of course, what was new at that time is old today, and of course some proposals that were new for cuisine were not for chemistry, or for other cultures. First let us observe that 'new' meant what was not found in professional occidental cuisine at the time. In 1969, Kurti proposed using some particular physical techniques such as a vacuum technique, ${ }^{42}$ and in 1984 I proposed looking at catalogues of hardware for chemistry laboratories, and trying to apply some of that in the kitchen. For example, using good fritted glass funnels and reduced pressure, the 'clarification' of ubiquitous meat stocks can be much improved and performed faster than using whipped egg white, simmering and filtering with cloth and a culinary sieve. Emulsions such as mayonnaise 
can be obtained very rapidly with no effort using ultrasonic probes. Rotary evaporation (much in favour in modern restaurants for some years) is very useful in order to recover odorant fractions of various foods. Or liquid nitrogen can be used to make better ice creams and sherbets (because of the smaller size of ice crystals).

Molecular cuisine is a developing culinary trend all over the world, now reaching countries such as Malaysia, Turkey, etc. Chefs using it are stars, shown to the public by all the world's media, to the point that some universities are now introducing educational curricula based on the appeal that such cuisine can exert on young students, who are attracted to science through cooking.

As this trend was developing, we proposed (this is not chemistry, but only using science for having ideas for artistic development) new lines, such as 'abstract cuisine' (as for painting, one prepares dishes that 'taste good', but in which no particular taste can be recognized), or 'culinary neo-impressionism' (based on the same ideas as neoimpressionism in painting), based on the ideas and discoveries of the French chemist Michel-Eugène Chevreul (1786-1889), who discovered both the molecular constitution of triacylglycerols and the law of the simultaneous contrast of colours, etc.

In particular, for many years, we have been using the knowledge of the chemistry and physics of food systems in order to propose new dishes to which the name of some famous scientist from the past was given. For example, emulsions trapped in chemical gels are called 'gibbs' in honour of the American chemist Josuah Willard Gibbs ; or 'würtz' are systems obtained by gellification of a foam, such as can be obtained by whipping a hot solution containing gelatine. And so on with 'vauquelin', 'liebig', 'nollet', 'lavoisier', 'geoffroy', 'kessel', 'priestley', 'chaptal' or 'gay-lussac'. ${ }^{15,43}$

\section{Note by Note Cuisine}

However, as all this was done many years ago, we felt that new ideas were needed, and a proposal made in $1994^{44}$ is now promoted under the name "note by note cuisine'. ${ }^{45}$ In order to explain this new practice, let us first note that traditional food is made primarily from mixtures of compounds, and that it is like music using traditional musical instruments. Using pure compounds to make food (this is the definition of note by note cuisine) is like acoustic music (using pure sound waves).

One could fear that note by note dishes would be more difficult to make than just cooking plant or animal tissues, but the same fear existed in music three or four decades ago. However, after some use of synthesizers, musicians learned to make their own, new, shortcuts, so that today most music on our radio is acoustic, partially or entirely. Yes, building dishes note by note will be slow when one works using pure compounds, but why not use the same methods as for music? After all perfumes are already composed in this way.

The public and even scientists are generally afraid of not by note cuisine. Are we going to get all needed nutriments, oligo-elements, vitamins? And toxicity: aren't these compounds dangerous? And consistency: don't you fear that it will be only liquids? And farming and agriculture: are they going to disappear? All arguments are used to justify that we keep our 'traditional food', made of cassoulets, stews, choucroute, etc. For all 
these foods, nutritional 'properties' are given with a lot of denial, because we 'love' them. However our denial based on food neophobia is not a reason for not assessing the interest of note by note cuisine. Moreover the advent of note by note cuisine will not kill traditional cuisine, but simply add to it.

Intellectually, note by note cuisine is very interesting, because it asks so many questions. ${ }^{37}$ The first one is to know the nature of the compounds that cooks can use. The culinary world is already using very pure compounds, such as water, sodium chloride, sucrose, gelatine, etc. The public often ignores that these compounds were prepared by the industry, through various extraction processes, purifications, various technological modifications (for example, anti-aggregation compounds are added to sucrose). Many other compounds could be prepared in the same way, such as saccharides and polysaccharides, amino acids and peptides, proteins, and so on, in particular because the food industry already prepares them, for formulation. For example, the industry of food additives produces pigments, vitamins, preservative agents, gelling or thickening. Certainly additives are not regulated as food ingredients, but could they not be so in the future?

On the other hand, the question of purity of compounds invites us to do the same thing as for music, that is to say to enlarge the list of usable compounds with simple mixtures, what the industry already makes from products based on the cracking of milk or grain. Gelatine, for example, is not pure, in the sense of being made of molecules of only one kind, because there is a strong molecular weight dispersion of the polypeptidic chains, due to the particular extraction performed to produce it. In addition, starch is not pure, as it is made of two main compounds, which are amylose and amylopectin (we should say 'amyloses', and 'amylopectines', because here again there is no homogeneity). In passing, let us not forget that as starch comes in this way in the list of compounds that one can use for note by note cuisine, most techniques of pastry can be used for making note by note cuisine.

Let us return to the question of 'cracking' plant or animal tissues, which is indeed preparing fractions. From grain, the industry extracts polysaccharides, proteins, amino acids, surfactants, etc. From milk, the industry recovers amino acids, peptides, proteins, glycerides, etc. Could not we do the same from plant or animal tissues? Could we not, using the same kind of processes, such as reverse osmosis, vacuum distillation, and so on, prepare quite 'pure' fractions, in order to practise note by note cuisine?

Many technology groups study this question, and colleagues at the Montpellier INRA Centre, for example, recently patented a technique based on reverse osmosis for the recovery of the total phenolics fraction from grape juice. Let us add that this fraction can be very different depending on the raw material, grape juice from Syrah, or from Grenache, or Pinot, for example: because the process does not produce perfectly pure products, the diversity of the initial products is not erased by the fractionalization process, so that cooks should be happy to play with the 'terroir'.

How to assemble compounds into dishes? Here we should remember that most of today's food actually categorizes as colloids, with often a large proportion of water in them. Many organic compounds are poorly soluble in water, and emulsification is obviously a very important process in note by note cuisine. It is not the only one, though; all dispersion techniques will be useful. During this assembly, the various biological 
properties of food will have to be considered: of course, the nutritional content is important, but it would be a mistake to forget that food has to stimulate the various sensory receptors: vision, odour, taste, the trigeminal system, temperature, etc.

Many questions are open now. For example, although we know how to determine the light absorption spectrum of a mixture of compounds in a mixture, and we know the individual absorption spectrum of each compound, we still cannot predict the 'colour' of the mixture. In addition, when one mixes odorant compounds in proportions close to the perception threshold, unpredictable odours are obtained. Worse, the mixture of only two odorant compounds is not a solved issue: do they make a 'chord' or a fusion?

For tastes, the question is even more serious, because we ignore their receptors and their substrates, and it was discovered recently (less than ten years ago) that the tongue also includes receptors for fatty acids with a long unsaturated chain. This means that other important discoveries can be made. In the meantime, one can use citric, malic, tartaric, acetic, ascorbic, or lactic acids. Or saccharides such as glucose, fructose, lactose, etc, and not only the old sucrose. For trigeminal effects, some 'fresh' or 'pungent' compounds are known, such as eugenol (in cloves), menthol (one of its enantiomers only), capsaicin (for chilli), piperin (for pepper), ethanol, sodium bicarbonate, and many others.

From the consistency point of view, again technological work can be done, because making colloidal materials continues to be insufficiently studied. Making simple emulsions is sometimes considered difficult, but more generally one should not consider that texturization of formulated products is a solved issue, even if we now have surimis and analogous systems. Who will succeed in making the consistency of a green apple? Or a pear? Of a strawberry? Not only is the question of laboratory prototypes not solved, but also the question of mass production is not considered (and this is why fruit companies providing products for the yogurt industry are so upset).

As a whole, much remains to be done, many questions have to be studied by science and by technology. Let us finish this section with an important observation: it would be uninteresting to 'reproduce' already existing food ingredients. As synthesizers can make sounds like that of the piano or violin, note by note cuisine could obviously reproduce wines, carrots, meats, etc, but why? Except for astronauts travelling for a long time, it is probably useless to make what already exists, and it is much more exciting to investigate flavours and dishes that were never envisioned using traditional food ingredients.

A simple calculation shows the immensity of the world to be discovered. If we assume that the number of traditional food ingredients is about 1000 and if we assume that a traditional recipe uses 10 food ingredients, the number of possibilities is 1000 to the power 10 , or 10 to the power 30 . However, if we assume that the number of compounds presents in food ingredients is about 1000, and if we assume that the number of compounds that will be used in note by note cuisine is of the order of 100, then the number of possibilities is about 10 to the power 3000 . And in this calculation we did not consider that the concentration of each compound can be adapted, which indeed means that a whole new continent of flavours can be discovered. Why reproduce our small world, then?

Many issues are now to be studied. Concerning the nutritional question, we should begin by admitting that traditional food is not a guarantee of healthy food: remember that there is today a pandemic of obesity. Of course, some will criticize the modern diet, but it 
would be rather more appropriate to observe that the new environment (high energy, little exercise) does not fit the traditional diet. Indeed, up to the last century, the human species had to face alternating times of plenty and starvation, and nutrigenomics is now discovering mechanisms through which the human body could manage these conditions. For example, too much to eat does not lead to increased elimination, as we could wish today, but rather better storage in fat tissues.

Note by note cuisine could be interesting nutritionally, because it could easily make 'low calorie' products, but here again questions are still unanswered. Do sweeteners lead to overconsumption? The studies that have already been made could guide the study of the long term effects of note by note cuisine. Certainly, the question of using vitamins or oligoelements, and also minor nutriments should be considered. It would be a mistake to consider that the issue is easy, as a European study of beta carotene supplements, the name given to a group of hydrophobic compounds with specific antioxidant properties, was stopped, because of the higher incidence of deaths in the group of smokers receiving the supplement.

The issue of regulation of food products will then be analogous to the question of selling liquid nitrogen to 'molecular cooks', of selling ultrasonic probes, of selling rotary evaporators. The evolution of practices will ask for new regulations, as was the case when gas or electricity were introduced in the home. And we should know that there will almost certainly be accidents, not because note by note cuisine is more dangerous than knives, or gas, but because the culinary world, as any specific community, has its proportion of careless people, for example the young German guy who put liquid nitrogen in a closed bottle in 2009.

For all those who are afraid of having to do without their stew, cassoulet or choucroute, let us say that as far as art is concerned, there is no replacement, but only addition, more freedom, more choice. Debussy did not make Mozart or Bach disappear; Picasso or Buffet did not prevent us from admiring Rembrandt or Brueghel. And molecular cuisine did not kill nouvelle cuisine or traditional cuisine. Note by note cuisine will be an artistic addition.

What will be the price of note by note cuisine? Will it be more expensive than current ways of cooking? Here the energetic issue has to be considered because the next increase of the cost of energy will perhaps be the key to the success of note by note cuisine. Today, in order to 'reduce' wine or bouillon, in view of making a sauce, cooks evaporate primarily water (losing many odorant compounds, lost by steam evaporation, on the way). If we assume a reduction such as done by professionals (for example by two thirds), a simple calculation shows that the energy consumed is $0.417 \mathrm{kWh}$, which means $€ 0.05$ per sauce.

More generally, the question of energy is not considered in traditional cuisine, where meats are heated to more than $200^{\circ} \mathrm{C}$, in order to produce compounds that could be immediately reached by note by note cuisine, and for which mass-produced compounds could be made at a much lower cost (roasting ten chickens in the same oven does not coast more than roasting one, which means that the cost per chicken drops).

On the other hand, it will not be necessary to synthesize the compounds used by cooks, and frequently they will be extracted, from plant material, such as chlorophylls today. Chemists know well that hundreds of chemist-years were necessary to synthesize vitamin B12, so that agriculture and extraction remain the most efficient method. Note by note can then use either synthesized or extracted products, no matter where they come from. 
The first tests of note by note cuisine inescapably created fear, based on the fantasy idea that we would eat 'chemicals'. Here, as for genetically modified organisms (GMO), for example, political ideas are confused with other questions. Note by note cuisine can be successful only when it is well explained, and if those in authority back it, as the pharmacist Augustin Parmentier understood very well when he served potatoes to the king of France at a time when the country refused to eat this food. But should we not be afraid that, as for GMO's, note by note cuisine will have disadvantages for human organizations? How would farmers survive if - although this is highly unlikely - all food should become note by note? These questions are more than chemists can answer, but they call for the following observation: as some people are rich by preparing wine instead of selling grapes, farmers could become richer than they are today if they produce fractions of plants, instead of selling the raw material.

Whatever the studies, note by note is already there, because we invited (and helped) the French chef Pierre Gagnaire (with restaurants in Paris, London, Tokyo, Dubai, HongKong, Moscow, Courchevel, Berlin, Las Vegas, Seoul) to be the first cook in the history of cooking to produce a fully note by note dish: after many months of work, we showed a note by note dish during a special dinner, in Hong Kong, on 24 April 2009. Then, during the summer 2010, the Alsatian cooks Hubert Maetz and Aline Kuentz made note by note dishes that they demonstrated during the French-German-Japanese Alumni Meeting (JSPS), in Strasbourg. Later, in October, the professors of the Cordon Bleu School, in Paris, made a whole note by note meal for a group of 20 participants of the curriculum of the Hautes Etudes du Goût (Advanced Studies in Gastronomy). In January 2011, the day before the official launching of the International Year of Chemistry, Jean-Pierre Biffi and his team of the catering company Potel \& Chabot made a note by note meal for more than 100 people, and more recently, in May 2011, the same meal was served to all chefs having won a Michelin star, at l'Espace Cardin, Paris. And so on.

On each occasion, the cooks had to look for compounds that they did not know, and they had to learn to use these products in order to make remarkable dishes, with new flavours. Of course, one can hardly explain the flavour of these dishes: how would you explain what the colour blue is to someone who cannot see? In addition, the question of the name of the dishes was difficult, but the perfume industry solved the issue: Chanel 5, Eau Sauvage, etc. For the note by note meal that was served the day before the official opening event of the International Year of Chemistry, in Paris, by the catering company Potel \& Chabot under the supervision of the chef Jean-Pierre Biffi, the written menu was: Tapioca oysters, Amylopectic Bavarian mousse, lime tapioca, Frozen sea water, oyster cream and crystallized vapour; Lobster soufflé, Wöhler sauce and raspberry agar jelly; Fibres of beef, Cappellini, kegs of carrots, Ox cheek with gravy; Blackcurrant powder surprise, Cassis ball; Pumpkin seed bread, Potel\&Chabot's loaf.

\section{From Schools to Universities}

It is frequently considered that technology is the application of science, but one should not forget that education is also a way of applying scientific results! Sciences change minds (remember the impact of the theory or evolution, of heliocentrism, of relativity, etc). Here, a 
new appreciation of food can result from the scientific exploration of cooking. Using the appeal of food, we devised a lot of educational programmes, from school up to university level; many such programmes are now being used in other countries.

First, in 2001, upon the invitation of the French Minister for Public Education, we set up a programme called Ateliers expérimentaux $d u$ goût, based both on a book ${ }^{46}$ and also keeping ideas from the Hands on programme in Chicago. In this programme, students learn to make chocolate mousse without eggs, or how to make one cubic metre of whipped egg white from one egg white, for example. In 2004, this programme was transferred up to high schools under the name Ateliers Science \& Cuisine. At the same time, the curriculum of culinary schools was corrected, and new methods were introduced (Ateliers expérimentaux), whereas new university programmes were introduced. Very recently, molecular gastronomy was included in a European Erasmus Mundus Master Programme (Food innovation and product design ${ }^{47}$ ), a collaboration between AgroParisTech (France), the Dublin Institute of Technology (Ireland), the University of Napoli (Italy) and the University of Lund (Sweden).

It is to be hoped that all these educational programmes, plus others that we cannot describe, will create a new generation of citizens, who will both appreciate the beauty of chemistry, and cook differently from our ancestors.

Celebrate chemistry!

\section{References}

1. http://sciencestudies.univie.ac.at/governing-futures-conference/, last accessed 27 December 2011.

2. http://www.nobelprize.org/, last accessed 28 December 2011.

3. H. This (2011) Cours de gastronomie moléculaire No. 2: les précisions culinaires (Paris: Quae/Belin).

4. M.-O. Monneuse, C.M. Hladik, B. Simmen and P. Pasquet (2011) Changes in food neophobia and food preferences during a weight reduction session: influence of taste acuity on the individual trajectory. In: V.R. Preedy, R.R. Watson \& C.R. Martin (Eds) The International Handbook of Behavior, Diet and Nutrition (New York: Springer-Verlag), pp. 1715-1730.

5. J.A. Chaptal (1800) Essai sur le perfectionnement des arts chimiques en France (Paris: Imprimerie nationale).

6. A.J. Ihde (1984) The Development of Modern Chemistry (Dover: Mineola).

7. Joint FAO/WHO Expert Committee on Food Additives, Summary Report of the Seventy-second meeting of JECFA, Rome, 16-25 February 2010.

8. H. This (2010) Kitchen Mysteries (New York: Columbia University Press).

9. B. de Sacchi (1473) De honesta voluptate et valetudine (Roma).

10. R.H. De Vos, W. Van Dokkum, A. Schouten and P. De JongBerkhout (1990) Polycyclic aromatic hydrocarbons in Dutch total diet samples (1984-1986). Food and Chemical Toxicology, 28, pp. 263-268.

11. International Agency for Research on Cancer (1990) Cancer: Causes, Occurrence and Control (Lyon: International Agency for Research on Cancer Scientific Publication no. 100).

12. European Commission, Scientific Committee on Food (2001) Opinion of the Scientific Committee on Food on Estragole (1-Allyl-4-methoxybenzene), SCF/CS/ FLAV/FLAVOUR/6 ADD2 FINAL, 26 September 2001. 
13. http://idiva.com/news-health/is-chocolate-good-for-your-health/2707, last accessed 27 December 2011.

14. J. Jacques (1987) Marcellin Berthelot, Autopsie d'un mythe (Paris: Belin).

15. G. Galilei (1992) Sidereus nuncius. Le messager céleste (Paris: Les Belles Lettres).

16. H. This (2009) Cours de gastronomie moléculaire No. 1: Science, technologie, technique (culinaires): quelles relations? (Paris: Editions Quae/Belin).

17. A. Einstein (1989) Correspondances Françaises (Paris: Le seuil/CNRS Editions).

18. P. Feyerabend (1987) Farewell to Reason (London, New York: Verso).

19. P. Thuillier (1988) D'Archimède à Einstein (Paris: Fayard).

20. Collective (1984) Larousse Gastronomique (Paris: Larousse).

21. H. This (2009) Kitchen Mysteries (New York: Columbia University Press).

22. H. This (2011) Pourquoi les soufflés gonflent, ou ne gonflent pas? La Cuisine collective, $\mathbf{2 3 7}$, pp. 6-8.

23. H. This (1995) La gastronomie moléculaire et physique. PhD dissertation, University Pierre et Marie Curie, Paris.

24. H. This (2010) Cours de gastronomie moléculaire No. 2: Les Précisions Culinaires (Paris: Editions Quae/Belin).

25. P. Belitz and W. Grosch (1987) Food Chemistry (Heidelberg: Springer-Verlag).

26. Académie des gastronomes, Académie culinaire de France (1991) L'art des sauces (Malakoff: L.T. Lanore).

27. H. This (2009) Molecular gastronomy, a chemical look to cooking. Accounts of Chemical Research, 42(5), pp. 575-583.

28. J. Zawistowski, C.G. Bibarderis and N.A.M. Eshin (1991) Oxidative Enzymes in Food, edited by D.S. Robinson, N.A.M. Eshin (London: Elsevier Applied Science), pp. 217-273.

29. http://www.thefatduck.co.uk/Heston-Blumenthal/Our-Awards/, last accessed 27 December 2011.

30. http://seas.harvard.edu/cooking, last accessed 27 December 2011.

31. http://old.iupac.org/reports/2001/colloid_2001/manual_of_s_and_t/node33.html, last access 27 December 2011.

32. H. This (2002) A new formalism for the description of complex disperse systems. Plenary lecture of the XVIth European Conference of the European Colloid and Interface Society ECIS, Paris.

33. H. This (2007) Formal descriptions for formulation. International Journal of Pharmaceutics, 344(1-2), pp. 4-8.

34. H. This (to be published) Formulation and new dishes (Paris: EDP Science, Cahiers de Formulation).

35. A. Cazor, C. Deborde, A. Moing, D. Rolin and H. This (2006) Sucrose, glucose and fructose extraction in aqueous carrot root extracts prepared at different temperatures by means of direct NMR measurements. Journal of Agricultural and Food Chemistry, 54, 4681-4686.

36. J. Valverde and H. This (2008) $1 \mathrm{H}$ NMR quantitative determination of photosynthetic pigments from green beans (Phaseolus vulgaris L.). Journal of Agricultural and Food Chemistry, 56(2), pp. 314-320.

37. A. Tardieu and H. This (2009) Comparison of mono- and disaccharides release in aqueous solutions by raw or fried dice of onion (Allium cepa L.) bulbs using quantitative nuclear magnetic resonance (qNMR). Journal of Food Science, 74(4), pp. 319-325.

38. A. Tardieu, W. de Man and H. This (2010) Using one dimensional (1D) and two dimensional (2D) quantitative proton $(1 \mathrm{H})$ nuclear magnetic resonance spectroscopy (q NMR) for the identification and quantification of taste compounds in raw onions 
(Allium cepa L.) bulbs and in aqueous solutions where onion tissues are soaked. Analytical \& Bioanalytical Chemistry, 398(7), pp. 3139-3153.

39. L. Weberskirch, A. Luna, S. Skoglund and H. This (2011) Comparison of two liquid-state NMR methods for the determination of saccharides in carrot (Daucus carota L.) roots. Analytical and Bioanalytical Chemistry, 399(1), pp. 483-487.

40. F. Davis, L.A. Terry, G.A. Chope and C.F.J. Faul (2007) Effect of extraction procedure on measured sugar concentrations in onion (Allium cepa L.) bulbs. Journal of Agricultural and Food Chemistry, pp. 4299-4306.

41. A. Tardieu, M. France and H. This (2011) The Effects of Sample Size and Temperature on the Water Soluble Compounds from Onions into Aqueous Solutions (European Symposium for Fruit and Vegetable Processing: Avignon).

42. N. Kurti (1969) The physicist in the kitchen. Proceedings of the Royal Institution, 42(199), pp. 451-467.

43. http://www.pierre-gagnaire.com/\#/pg/pierre_et_herve, last access 27 December 2011.

44. H. This and N. Kurti (1994) Chemistry and physics in the kitchen. Scientific American, 270(4), pp. 44-50.

45. H. This (2011) La cuisine note à note. L'Actualité chimique, 350, pp. 5-9.

46. H. This (1999) La casserole des enfants (Paris: Belin).

47. www.fipdes.eu, last access 27 December 2011. 